Прокопів М.М., Слабкий Г.О.

\title{
Методичні підходи до створення сучасної системи надання медичної допомоги хворим на цереброваскулярні захворювання в мегаполісі
}

\author{
Національний медичний університет ім. О.О.Богомольця, м. Київ, Україна \\ ДВНЗ «Ужгородський національний університет», м. Ужгород, Україна
}

\begin{abstract}
Мета роботи - розробити та представити методичні підходи до створення сучасної системи надання медичної допомоги хворим на церебральний інсульт в мегаполісі.

Матеріали та методи. При виконанні дослідження були використані бібілосемантичний метод та метод структурно-логічного аналізу. Методичною основою дослідження став системний підхід. Матеріалами дослідження слугували документи ВООЗ з питань ЦВЗ та иееребральних інсультів та законодавчі акти Украӥни з реформування системи охорони здоров'я в державі.

Результати. Спираючись на Свропейський план дій із боротьби з інсультом розроблено методичні підходи до створення сучасної системи надання медччної допомоги хворим на цереброваскулярні захворювання в мегаполісі. Методичні підходи передбачають комплексну трьохрівневу профілактичну роботу яку мають проводити як працівники системи надання медичної допомоги так і системи громадського здоров'я. Складовою системи $\epsilon$ структурні та організаційні перетворення скеровані на забезпечення хворих доступною, своєчасною та якісною медичною допомогою. Основою створення системи є розробка комплексної міжсекторальної міської програми боротьби з інсультом як ускладнення цереброваскулярних захворювань.

Висновки. Впровадження сучасної системи надання медичної допомоги при ичереброваскулярних хворобах дозволить зменшити рівень ускладнень та скорити їх негативні медико-демографічні наслідки шляхом застосування комплексних профілактичних заходів, формування у населення відповідального ставлення до особистого здоров'я та надання своєчасної і ефективної медччної допомоги.

Ключові слова: иереброваскулярні захворювання, медична допомога, сучасна система, методичні підходи.
\end{abstract}

\section{Вступ}

3 а даними ВООЗ у світі щорічно реєструється біля 7,6 млн випадків смертей в результаті цереброваскулярних захворювань $[8,12]$.

Відповідно до прогнозів міжнародних експертів, у найближчі 10-20 років очікується глобальний ріст захворювань головного мозку судинного генезу, що пов'язано з постарінням населення, урбанізацією i нездоровим способом життя [9, 12].

В Україні серцево-судинна i судинно-мозкова патологія є причиною біля $2 / 3$ випадків смертей і $1 / 3$ випадків інвалідності, що скорочує тривалість життя населення [3]. За даними МО3 України, в країні нараховується більше 3 млн хворих $(6,4 \%$ всього населення) різними судинними захворюваннями головного мозку, інсульт був зареєстрований майже у 120 тис. українців [14]. Кожні 5 хвилин захворювала i кожні 15 хвилин - одна людина помирала від гострого порушення мозкового кровообігу [6].

В зв'язку 3 постійним зростанням кількості населення. яке хворіє на цереброваскулярні захворювання попередження їх прогресування та покращення якості їх життя $\epsilon$ однією із важливих задач системи охорони здоров'я [13].

В Україні проводиться реформування системи надання медичної допомоги 3 пріоритетним розвитком первинної медичної допомоги на засадах загальної лікарської практики-сімейної медицини $[1,4,10,11]$, розвитку системи громадського здоров'я та впровадження пакету гарантованого державною безоплатного пакету медичної допомоги $[2,7]$.

В таких умовах наукове обгрунтування потребує формування якісно нової системи нейрохірургічної допомоги, що і обгрунтувало актуальність дослідження, визначило його мету та завдання.

Мета роботи - розробити та представити методичні підходи до створення сучасної системи надання медичної допомоги хворим на церебральні хвороби в мегаполісі

\section{Матеріали та методи}

При виконанні дослідження були використані бібілосемантичний метод та метод структурно-логічного аналізу. Методичною основою дослідження став системний підхід. Матеріалами дослідження слугували документи ВООЗ з питань ЦВЗ та церебральних інсультів та законодавчі акти України 3 реформування системи охорони здоров’я в державі.

\section{Результати дослідження та їх обговорення}

Основною задачею, яка стоїть перед системою охорони здоров'я є профілактична робота серед населення 
мегаполісу. Необхідно акцентувати на проведенні первинної, вторинної та третинної профілактики. Для охоплення населення профілактичними програмами необхідно виділити цільові групи профілактичного впливу та заклади, які будуть проводити дану роботу i безпосередніх виконавців.

Цільовими групами для проведення різних видів профілактичної роботи мають бути:

1) Первинна профілактика: доросле населення міста, особливу групу складає населення міста у віці 40 років і старше, а серед даного населення групу підвищеної уваги займають особи груп ризику розвитку ЦВЗ;

2) Вторинна профілактика: особи, які мають цереброваскулярні захворювання та гіпертонічну хвороби;

3) Третинна профілактика: особи, які перенесли гострий церебральний інсульт.

Профілактичні програми полягають в наступному.

Первинна профілактика. Даний вид профілактики мають здійснювати служби громадського здоров'я та працівники закладів первинної медико-санітарної допомоги.

Служби громадського здоров'я здійснюють свою діяльність в рамках виконання наступних основних оперативних функцій, які затверджені ВООЗ: ООФГЗ 1 «Епіднагляд за хворобами та оцінка стану здоров'я та благополуччя населення», ООФГЗ 2 «Виявлення важливих медико-санітарних проблем та загроз здоров'ю на рівні місцевих громад», ООФГЗ 5 «Профілактика хвороб», ООФГЗ 6 «Укріплення здоров'я», ООФГЗ 9 «Основні процеси комунікацій в області громадського здоров'я». В рамках діяльності системи громадського здоров'я проводиться епідеміологічний нагляд, моніторинг, оцінка та аналіз захворюваності різних категорій населення на ЦВЗ та рівень їх поширення серед населення, вплив ЦВЗ на інвалідності та смертності населення внаслідок ЦВЗ, вивчаються фактори ризику розвитку ЦВЗ та інформується населення про них та шляхи зменшення їх негативного впливу на здоров'я шляхом розроблення та впровадження профілактичних програм на рівні громади з оздоровлення навколишнього середовища, умов праці, проживання та створення умов для здорового способу життя. Також проводяться заходи 3 формування у населення відповідального ставлення до особистого здоров'я.

Сімейні лікарі та сімейні медичні сестри здійснюють індивідуальні заходи з цільової диспансеризації населення щодо цереброваскулярних захворювань: 3 використанням уніфікованого опитувальника проводять виявлення факторів ризику різних форм цереброваскулярних захворювань 3 розробкою індивідуальних програм їх усунення або зменшення негативної дії.

Вторинна профілактика.

Вторинною профілактикою охоплюються особи у яких діагностовано ЦВ3 і вона скерована на попередження подальшого розвитку захворювання та профілактику ускладнень і в першу чергу церебрального інсульту. Це здійснюють працівники первинної ланки.

Основними напрямками вторинної профілактики за розробленого для кожної особи індивідуального плану являються:
- оптимальний спосіб життя, який формується в залежності від стадії захворювання та стану хворої особи;

- медикаментозна та фізична терапія скеровані на: покращення загального та мозкового кровоточу, покращення функції мозкових клітин, які знаходяться в умовах гіпоксії за рахунок посилення перфузії кисню, зменшення в'язкості крові та попередження розладів проникності стінок судин i нормалізація стану переваскулярних тканин.

При цьому служби громадського здоров'я, використовуючи мобільні телефони та відповідні інформаційні програми, підключають нагадувачі про час прийняття лікарських засобів. Крім того з особами, які страждають на ЦВЗ проводяться заняття та вони забезпечуються друкованою інформацією щодо симптомів загрозливих для життя та тактики дії при них, телефони для звернення в ургентних випадках за медичною допомогою.

Третинна профілактика. Даний вид профілактики передбачає попередження повторних церебральних інсультів у осіб, які мали в анамнезі дане ускладнення та запобігання інвалідності. Даний вид робіт забезпечують сімейні лікарі сумісно 3 лікарями неврологами. А забезпечення медико-соціального супроводу осіб, які перенесли гострий церебральний інсульт і стали інвалідами забезпечують працівники первинної медико-санітарної допомоги та соціальних служб. Вони ж забезпечують, по необхідності, послугами паліативної допомоги.

Враховуючи, що в Україні державою гарантована безоплатна медична допомога хворим на церебральні інсульти, включаючи проведення реабілітації осіб, що його перенесли на після госпітальному етапі i що у 2020 році на виконання Закону України "Про державні фінансові гарантії медичного обслуговування населення" Програма медичних гарантій запрацює в повному обсязі пропонується здійснити наступні структурні перебудови:
1. Створити інсультні центри структура, оснащення, штатні розклади яких повністю відповідають вимогам в рамках забезпечення програми державних гарантій надання медичної допомоги при церебральному інсульті в 2020 році. Кількість центрів та їх потужність обраховуються на основі показників захворюваності за останні 5 років.

2. Створити спеціалізований реабілітаційний центр для осіб, що перенесли гострий церебральний інсульт для проведення стаціонарної та амбулаторної реабілітації.

3. Здійснити підготовку сімейних лікарів та сімейних медичних сестер до забезпечення реабілітації осіб, що перенесли церебральний інсульт. За рахунок коштів місцевих бюджетів укомплектувати сімейні амбулаторії засобами амбулаторної реабілітації.

Необхідно провести наступні організаційні заходи:

1. Базуючись на Європейському плані дій із боротьби з інсультом - ESAP на період 2018-2030 роки розробити комплексну міжсекторальну міську програму боротьби з інсультом як ускладнення цереброваскулярних захворювань.

2. Проводити інформаційну роботу серед населення міста з залученням 3МІ та мережі інтернет із створенням спеціального сайту щодо цереброваскулярних хвороб та їх профілактики. 
3. Розроблення та затвердження клінічних маршрутів пацієнтів які проживають в різних районах міста в залежності від місця та способу звернення за медичною допомогою та стану.

4. При зверненні за медичною допомогою до служби екстреної медичної допомоги та потреби в госпіталізації запровадження системи попереднього інформування закладу охорони здоров'я про наближення пацієнта з гострим церебральним інсультом для активації ресурсів закладу охорони здоров'я з метою забезпечення можливості проведення реваскуляризаційної терапії в межах терапевтичного вікна.

5. Забезпечити спеціального навчання всіх медичних працівників, які залучені до надання допомоги хворим при гострому церебральному інсульті (лікарі, середній та молодший медичний персонал), на тренінгах 3 тромболітичної терапії, інтенсивної терапії, використання шкал (NIHSS, ASPECTS, mRS), скринінгу щодо дисфагії, оцінювання потреби у реабілітації.

6. Організація для родини / доглядачів за хворими з ЦВ3 та їх ускладеннями постійно діючого семінару 3 наступних питань: методи особистої гігієни, стратегії спілкування, техніки переміщення, профілактики ускладнень та інших специфічних проблем пов'язаних 3 гострим церебральним інсультом, контроль за безпечним ковтанням та відповідної зміни дієти, допомоги регулювання поведінки при психосоціальних проблемах.

7. Створення міського реєстру хворих на ЦВЗ та осіб, що перенесли гострий церебральний інсульт 3 поданням даних до Електронної системи охорони здоров'я на постійній основі.

8. Для хворих на ЦВЗ та осіб, що перенесли гострий церебральний інсульт забезпечення розробку індивідуальної програми реабілітації з оцінкою проблем (категоріальний профіль МКФ та МКФ-ДП) та визначенням SMART цілей та здійснення контролю за виконанням індивідуальної програми реабілітації 3 оцінюванням прогресу в досягненні намічених цілей.

\section{Висновки}

Спираючись на Європейський план дій із боротьби з інсультом розроблено методичні підходи до створення сучасної системи надання медичної допомоги хворим на церебральний інсульт в мегаполісі. Методичні підходи передбачають комплексну трьохрівневу профілактичну роботу яку мають проводити як працівники системи надання медичної допомоги так і системи громадського здоров'я. Складовою системи є структурні та організаційні перетворення скеровані на забезпечення хворих доступною, своєчасною та якісною медичною допомогою. Основою створення системи $є$ розробка комплексної міжсекторальної міської програми боротьби 3 інсультом як ускладнення цереброваскулярних захворювань. Впровадження сучасної системи надання медичної допомоги при цереброваскулярних хворобах дозволить зменшити рівень ускладнень та скорити їх негативні медико-демографічні наслідки шляхом застосування комплексних профілактичних заходів, формування у населення відповідального ставлення до особистого здоров'я та надання своєчасної і ефективної медичної допомоги.

Перспективи подальших досліджень пов'язані 3 вивченням ефективності організації медичної допомоги хворим на церебральний інсульт в мегаполісі на первинному рівні ії надання.

\section{Література}

1. Доклад о состоянии здравоохранения в мире, 2008 г. Первичная медико-санитарная помощь - сегодня актуальнее, чем когда-либо. Женева, Всемирная организация здравоохранения, 2008. [Електронний ресурс]. - Режим доступу: http://www.who.int/whr/2008/whr08_ru.pdf. - Название с экрана.

2. Закон України „Про державні фінансові гарантії медичного обслуговування населення” 19 жовтня 2017 року № 2168-VIII [Електронний ресурс]. - Режим доступу: http://search.ligazakon.ua/1_doc2.nsf/link1/T172168.html. Назва з екрану.

3. Корнацький В.М., Ревенько І.Л. Соціальні та медичні проблеми цереброваскулярної патології. Укр. кардіол. журнал, 2008, 2: 12-18.

4. Лехан В. М. Інноваційні підходи до забезпечення доступності первинної медико-санітарної допомоги сільському населенню / В. М. Лехан, К. О. Надутий, Г. О. Слабкий // Україна. Здоров’я нації. - 2011. - № 3 (19). C. 86-91.

5. Мищенко Т.С. Епідеміологія цереброваскулярних захворювань в Україні // Судинні захворювання головного мозку. -2006 . - № 1. - С. 3-7.

6. Мищенко Т.С., Здесенко І.В., Колянко О.І. Епідеміологія мозкового інсульту в Україні // Український вісник психоневрології. - 2005. - Т. 13, вип. 1 (42). - С. 23-28.

7. Постанова КМУ „Про затвердження Порядку реалізації державних гарантій медичного обслуговування населення за програмою медичних гарантій для первинної медичної допомоги на 2018 рік” від 25.04 .2018 р. № 407 [Електронний ресурс]. Режим доступу: https://www.apteka.ua/article/458646. - Назва з екрану.

8. Рингач Н.О. Передчасна смерть населення України: вікові особливості / Н.О. Рингач // Україна. Здоров’я нації. - 2007. - № 3-4. - С. 16-19.

9. Сквориова В.И., Чазова Е.И., Стаховская Л.В. Вторичная профилактикаинсульта. М.: ПАГРИ, $2002 ; 120$ с.

10. Слабкий Г. О. Пріоритетний розвиток первинної медико-санітарної допомоги на засадах сімейної медицини / Г. О. Слабкий, І. С. Зозуля, А. І. Зозуля // Сімейна медицина. - 2014. - № 3 (53). - С. $25-27$. 
11. Слабкий Г.О., Орда О.М., Чепелевська Л.А., Любінець О.В. Сучасні та прогнозні тенденції смертності населення України. - Київ, 2010. - 177 с.

12. Суслина 3. А. Инсульт: диагностика, лечение, профилактика / 3. А. Суслина, М. А. Пирадов. М. : МЕДпресс-информ, 2008. - 288 с.

13. Суслина 3.А., Варакин Ю.Я., Верещагин Н.В. Сосудистые заболевания головного мозга: Эпидемиология. Патогенетические механизмы. Профилактика. М.:МЕДпресс-информ, 2009;352 с.

14. Щорічна доповідь про стан здоров'я населення, санітарно-епідемічну ситуацію та результати діяльності системи охорони здоров’я України. 2015 рік / за ред. Шафранського В. В. ; МОЗ України, ДУ «УІСД МОЗ України». Київ, 2016. - 452 с.

Дата надходження рукопису до редакиіï: 30.09.2019 р.

\begin{abstract}
Методические подходы к созданию современной системы оказания медицинской помощи больным с цереброваскулярными заболеваниями в мегаполисе
\end{abstract}

Прокопив М.М., Слабкий Г.А. Национальный медицинский университет им. А.А. Богомольца Ужгородский национальный университет

Цель работы: разработать методические подходы к созданию современной системы оказания медицинской помощи больным с цереброваскулярными заболеваниями в мегаполисе.

Методы: библиосемантический метод и метод структурно-логического анализа, системный подход. Материалы: документы ВО3 по вопросам цереброваскулярных заболеваний и законодательные акты Украины по реформированию системы здравоохранения.

Результаты. Опираясь на Европейский план действий по борьбе с инсультом разработаны методические подходы к созданию современной системы оказания медицинской помощи больным с цереброваскулярными заболеваниями в мегаполисе. Они предусматривают комплексную профилактическую работу, структурные и организационные преобразования, направленные на обеспечение больных доступной, своевременной и качественной медицинской помощью. Основой создания системы является разработка комплексной межсекторальной городской программы борьбы с инсультом как осложнением цереброваскулярных заболеваний.

Выводы. Внедрение современной системы оказания медицинской помощи при цереброваскулярных заболеваниях позволит снизить уровень осложнений и сократить их негативные медико-демографические последствия.

Ключевые слова: цереброваскулярные заболевания, медицинская помощь, современная система, методические подходы.

\section{Methodological approaches to creation of modern system of medical care for patients with cerebrovascular diseases in megapolis}

Prokopiv M.M., Slabkiy G.O.
National Medical University
named after O.O. Bohomolets
Uzhhorod National University

Goal of research: to develop methodological approaches to creation of modern system of medical care for patients with cerebrovascular diseases in megapolis.

Methods: bibliosemantic method and method of structural-and-logical analysis, systematic approach. Materials: WHO documents on the issues of cerebrovascular disease and legislative acts of Ukraine on the reforming of healthcare system.

Results. The methodological approaches to the creation of a modern system of medical care for patients with cerebrovascular disease in megapolis were developed based on the European Plan of Action for combat stroke. They provide for comprehensive preventive work, structural and organizational transformations aimed at providing patients with available, timely and qualified medical help. The development of comprehensive cross-sectoral urban program to combat stroke as a complication of cerebrovascular disease is the foundation for system creation.

Conclusions. The introduction of the modern system of medical care at cerebrovascular diseases will give possibility to reduce complications and to conquer their negative medical and demographic consequences.

Key words: cerebrovascular diseases, medical care, modern system, methodologic approaches.

\section{Відомості про авторів}

Прокопів Марія Мирославівна - к.мед.н., доц., доцент кафедри неврології Національного медичного університету імені О.О. Богомольця; м. Київ, бул. Т. Шевченка, 13.

Слабкий Геннадій Олексійович - д.мед.н., проф., завідувач кафедри наук про здоров’я ДВНЗ «Ужгородський національний університет»; м. Ужгород, пл. Народна 1, Україна, 88000. 